\title{
Sven Thatje · Erika Mutschke \\ Distribution of abundance, biomass, production and productivity of macrozoobenthos in the sub-Antarctic Magellan Province (South America)
}

Accepted: 21 December 1998

\begin{abstract}
Distribution of abundance, biomass, productivity and production of macrozoobenthos was investigated in four study areas in the Magellan region (South Patagonian Ice-Field, Strait of Magellan, Beagle Channel, Continental Shelf). Using a Reineck box corer and a multibox corer, a total of 277 quantitative benthos samples were taken at 78 stations in water depths between 8 and 1139 m during the Joint Chilean-GermanItalian Magellan "Victor-Hensen Campaign" in 1994, the "Polarstern" expedition ANT XIII/4 in 1996 and the Chilean expeditions "Cimar Fiordo II + III" in 1996 and 1997, respectively, on board RV "Vidal Gormaz". Mean abundance in the South Patagonian Ice-Field was significantly lower than in the Strait of Magellan and the Beagle Channel. Biomass and abundance decreased clearly with depth (20-300 m to 700-1500 m: $3.9 \mathrm{gC} \mathrm{m}^{-2}$ to $0.6 \mathrm{gC} \mathrm{m}^{-2} ; 2832$ ind. $\mathrm{m}^{-2}$ to 569 ind. $\mathrm{m}^{-2}$ ). Average abundance, biomass and production of the whole Magellan region are lower (2318 ind. $\mathrm{m}^{-2}, 3.2 \mathrm{gC} \mathrm{m}^{-2}$, $0.62 \mathrm{gC} \mathrm{m}^{-2}$ year $^{-1}$ ) than in the high Antarctic Weddell Sea. In the Magellan region, macrozoobenthos composition of abundance is mainly dominated by polychaetes $(56 \%)$, followed by arthropods (16\%), echinoderms $(10 \%)$ and molluscs $(11 \%)$. Comparisons of our present results with those of high Antarctic areas make it clear that the Magellan region has a transitional character.
\end{abstract}

\section{Introduction}

The Magellan region is one of the three classical Antarctic biogeographic provinces and the last one to sep-

\footnotetext{
S. Thatje $(\bowtie)$

Alfred Wegener Institute for Polar and Marine Research,

P.O. Box 120161, D-27576 Bremerhaven, Germany

(e-mail: sthatje@awi-bremerhaven.de)

E. Mutschke

Instituto de la Patagonia, Universidad de Magallanes,

Punta Arenas, Chile
}

arate from the Gondwana super-continent, a process that may have ended only about 20 million years ago (Brandt 1991; Arntz et al. 1994).

During the last decade comprehensive investigations were performed to extend the restricted knowledge about the marine life and environmental conditions of this area. Our knowledge about macrobenthic communities in the southernmost part of Chile is still limited and, therefore, data from this area are of great scientific interest. It is not clear, for instance, to what extent the macrobenthos of the southernmost tip of America and the Antarctic are related. For instance, we know that there are still conspicuous similarities, as shown by Linse (1997) for the molluscan fauna of both areas. However, brachyuran crabs are known to occur only in South America (Gorny, in press).

In order to provide information about general differences on the level of community, this work summarizes and extends the present knowledge about macrozoobenthos in the Magellan region on the basis of quantitative bottom samples.

\section{Materials and methods}

Data collection and analysis

Macrobenthos data obtained within the "Joint Victor Hensen Campaign 1994" (Arntz and Gorny 1996), the Chilean expeditions "Cimar Fiordo II + III" (Mutschke et al. 1995) and the "Polarstern" expedition ANT XIII/4 in 1996 (Fahrbach and Gerdes 1997) are the basis for this study.

In the Magellan region a total of 277 cores were obtained from 78 stations in four subareas (Fig. 1): the "South Patagonian IceField" (SPI: area I), the "Strait of Magellan" (area II), the "Beagle Channel" (area III) and area IV, which represents "continental shelf-stations" at the eastern entrance of the Beagle Channel. This division of the study area is consistent with previous investigations (Mariani et al. 1996; Brey and Gerdes, in press; Gerdes and Montiel, in press).

Sampling from onboard RV "Vidal Gormaz" was performed with a Reineck box corer (Reineck 1963), whereas a multibox corer (Gerdes 1990) was used from onboard the RVs "Victor Hensen" 
Fig. 1 Sampling sites in the four Chilean subareas

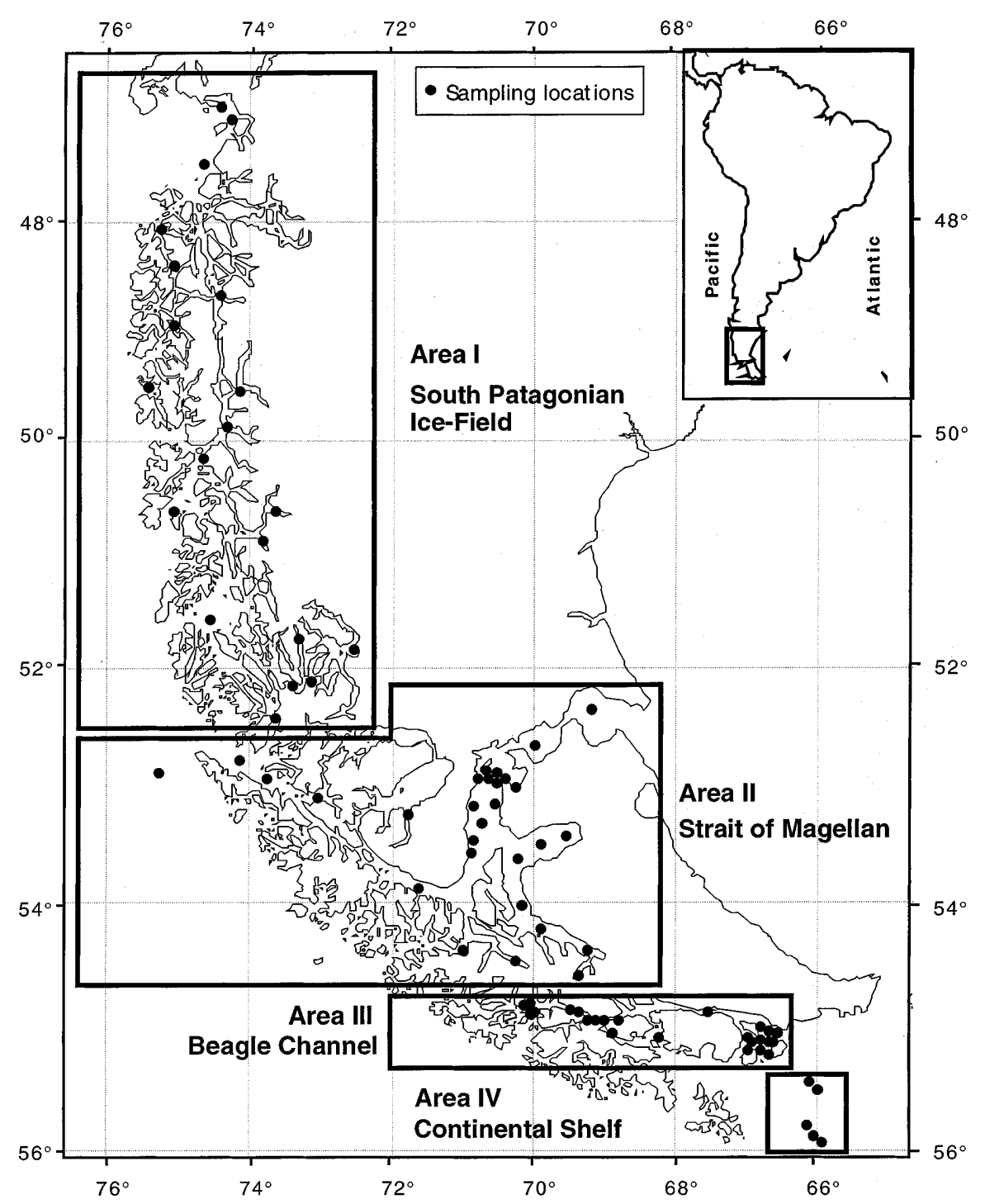

depth and temperature as input variables. Annual production was computed from the $\mathrm{P} / \mathrm{B}$ values and group biomass. Brey et al. (1996) showed the sum of production values obtained by such an approach for populations or, as in our case, taxonomic groups to be a reasonable estimate of total community production.

\section{Results}

The South Patagonian Ice Field showed the lowest abundance (627 ind $\mathrm{m}^{-2}$ ), biomass $\left(2.1 \mathrm{gC} \mathrm{m}^{-2}\right)$, production $\left(0.393 \mathrm{gC} \mathrm{m}^{-2}\right.$ year $\left.^{-1}\right)$ and $\mathrm{P} / \mathrm{B}$ ratio $(0.181$ year $^{-1}$, Table 1).

$\mathrm{P} / \mathrm{B}$ ratio estimates were in the same range in all subareas of the Magellan region, whereas biomass increased southwards to the Beagle Channel $\left(5.2 \mathrm{gC} \mathrm{m}^{-2}\right)$, as did abundance (4467 ind. $\mathrm{m}^{-2}$ ) and production (1.108 $\mathrm{gC} \mathrm{m}^{-2}$ year $^{-1}$, Table 1). A subsequent GamesHowell post-hoc test showed the benthos abundance in the SPI to differ significantly $(P=0.0019)$ from the
For each taxonomic group, we estimated annual $\mathrm{P} / \mathrm{B}$ by the artificial neural network of Brey et al. (1996), which uses parameters such as mean body mass, living mode, feeding type, taxon, water and "Polarstern". The samples were sieved on 0.5 -mm mesh and to sorting in the laboratory. Animals were classified into 38 ta values, the colonial Hydrozoa and Bryozoa were only considered as Wresent $\left(1\right.$ ind. $\left.\mathrm{m}^{-2}\right)$ specific conversion factors published by Cummins and Wuycheck Barthel 1995. and subsequent Games-Howell post-hoc test by differences on means.

\section{Estimation of annual production/biomass ratio and production}


Table 1 Benthos data obtained from the four Chilean subareas in the Magellan region

\begin{tabular}{|c|c|c|c|c|}
\hline & $\begin{array}{l}\text { South Patagonian } \\
\text { Ice Field (area I) }\end{array}$ & $\begin{array}{l}\text { Strait of Magellan } \\
\text { (area II) }\end{array}$ & $\begin{array}{l}\text { Beagle } \\
\text { Channel (area III) }\end{array}$ & $\begin{array}{l}\text { Continental Shelf } \\
\text { (area IV) }\end{array}$ \\
\hline No. of stations (no. of cores) & $20(42)^{\mathrm{a}}$ & $29(94)^{\mathrm{a}, \mathrm{b}}$ & $23(119)^{\mathrm{a}, \mathrm{b}}$ & $5(31)^{\mathrm{b}}$ \\
\hline Depth range $(\mathrm{m})$ & $20-711$ & $8-571$ & $14-348$ & $102-1139$ \\
\hline Mean biomass $\left(\mathrm{gC} \mathrm{m}^{-2}\right)$ & $2.1 \pm 0.155$ & $2.7 \pm 0.173$ & $5.2 \pm 0.290$ & $2.9 \pm 0.178$ \\
\hline Min.-max. biomass $\left(\mathrm{gC} \mathrm{m}^{-2}\right)$ & $0.01-17.35$ & $0.16-22.88$ & $0.54-16.99$ & $0.05-14.51$ \\
\hline Mean abundance (ind. $\mathrm{m}^{-2}$ ) & $627 \pm 65.4$ & $1857 \pm 197.5$ & $4467 \pm 468.3$ & $2319 \pm 193.1$ \\
\hline Min.-max. abundance (ind. $\mathrm{m}^{-2}$ ) & $30-1245$ & $174-4972$ & $668-13521$ & $1136-4379$ \\
\hline Annual production $\left(\mathrm{gC} \mathrm{m}^{-2}\right)$ & 0.393 & 0.738 & 1.108 & 0.684 \\
\hline $\mathrm{P} / \mathrm{B}$ ratio $\left(\mathrm{gC} \mathrm{m}^{-2}\right)$ & 0.181 & 0.261 & 0.208 & 0.236 \\
\hline
\end{tabular}

${ }^{\text {a }}$ Reineck box corer

${ }^{\mathrm{b}}$ Multibox corer

Strait of Magellan (area II) and the Beagle Channel (area III), whereas biomass and production showed no significant difference among all areas under investigation $(P=0.69, P=0.77)$.

The Chilean sampling sites were characterized by a strong heterogeneity of abundance and biomass (Table 1). However, average abundance and biomass decreased clearly with depth (Table 2).

In the Chilean fjord and channel areas (regions I, II and III), the macrozoobenthic abundance is mainly dominated by Polychaeta $(>60 \%)$, followed by Arthropoda ( $>12 \%$ ) and Mollusca ( $>7 \%$; Fig. 2a). Area IV, the continental slope, was distinctly different in faunal composition, due largely to the increased abundance shares of echinoderms $(34 \%)$ and the higher significance of Bryozoa, making up $24 \%$ of the biomass. Porifera were less important in the Magellan region; only in the Strait of Magellan (area II) do they represent $10 \%$ of the biomass (Fig. 2b).

\section{Discussion}

\section{Sampling}

Sampling in the SPI was performed with the Reineck box corer (Reineck 1963) and at the continental slope with the multibox corer (Gerdes 1990), whereas both methods were used in the Strait of Magellan and the Beagle Channel. Both gears are based on a similar mechanical principle, but the Reineck box corer is a singlebox corer covering $0.017 \mathrm{~m}^{2}$ whereas the multibox corer takes up to nine cores simultaneously which cover a sampling area of $0.066 \mathrm{~m}^{2}$ each. Up to eight of these cores per station were used for macrobenthos analyses. With the Reineck box corer, up to three cores per station were obtained. The multibox corer allows multiple sampling and may yield a better evaluation of benthic densities, especially of those that are usually patchily distributed (Gerdes 1990). Based on this, we do not think that our results are heavily biased by these different techniques.

Sampling by grabs is generally known to underestimate rare and large epibenthic species or those that are highly motile and can easily escape. Dahm (1996), for instance, showed that density assessments based on multibox cores underestimated ophiuroid abundances by a factor of 3 in the Weddell Sea. Likewise, crustaceans, especially larger decapods such as Peltarion spinosulum or Munida subrugosa, were not found frequently in our samples, though they are known to occur in high numbers in the Magellan region (Gorny, in press).

\section{Macrobenthos patterns in relation to the environment}

The South American sampling area belongs to the coldtemperate region (Brattström and Johanssen 1983). It is a very heterogenous shelf area with thousands of islands and many channels and fjords. Differences among the benthic communities are assumed to reflect these variable environmental conditions in the four Chilean subareas. The SPI $\left(48^{\circ} 20^{\prime} \mathrm{S}-53^{\circ} 30^{\prime} \mathrm{S}\right)$ is the largest midlatitudinal and meridional ice mass, covering an area of about 13,000 $\mathrm{km}^{2}$ (Warren and Sugden 1993). The channels and fjords of this area are heavily influenced by fresh water originating from the run-off of melting gla-
Table 2 Depth distribution of macrozoobenthos in the Magellan region

\begin{tabular}{|c|c|c|c|c|c|}
\hline Depth range & No. of stations & $\begin{array}{l}\text { Mean } N \\
\text { (ind. } \mathrm{m}^{-2} \text { ) }\end{array}$ & $\begin{array}{l}\text { Range } \\
\text { (ind. } \mathrm{m}^{-2} \text { ) }\end{array}$ & $\begin{array}{l}\text { Mean biomass } \\
\left(\mathrm{gC} \mathrm{m}^{-2}\right)\end{array}$ & $\begin{array}{l}\text { Range } \\
\left(\mathrm{gC} \mathrm{m}^{-2}\right)\end{array}$ \\
\hline $8-100 \mathrm{~m}$ & 26 & 3639 & 296-13521 & 5.041 & $0.38-22.88$ \\
\hline $101-300 \mathrm{~m}$ & 34 & 2025 & $30-6680$ & 2.842 & $<0.01-16.99$ \\
\hline $301-500 \mathrm{~m}$ & 9 & 1024 & $385-2807$ & 1.075 & $0.04-3.33$ \\
\hline $501-700 \mathrm{~m}$ & 7 & 750 & $296-1245$ & 1.423 & $0.01-9.44$ \\
\hline $701-1500 \mathrm{~m}$ & 2 & 569 & 89-1049 & 0.618 & $<0.01-1.23$ \\
\hline
\end{tabular}




\section{Area I South Patagonian Ice-Field}

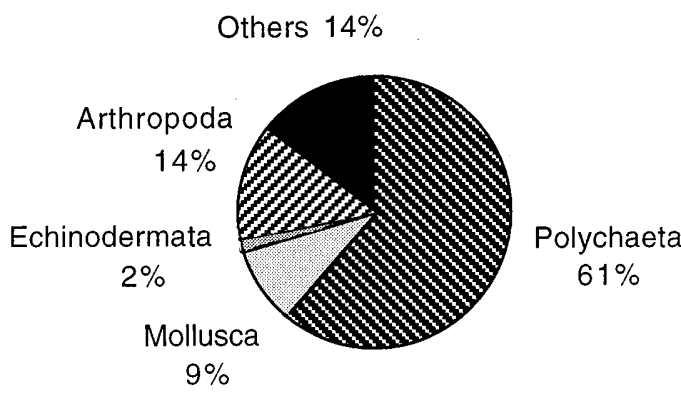

Arthropoda: Crustacea sp. $74 \%$ Pantopoda 5\% Ostracoda $३ \%$ Amphipoda 14\% Cumacea $2 \%$ Cirripedia $2 \%$

Mollusca: Bivalvia $85 \%$ Scaphopoda $12 \%$ Gastropoda 3\%
Echinodermata:

Echinoidea $31 \%$ Holothuroidea $31 \%$ Ophiuroidea $28 \%$ Asteroidea 10\%

Others: Vermes sp. $50 \%$ Sipunculida $23 \%$ Unidentified $17 \%$ Priapulida $6 \%$ Tunicata $4 \%$

Hydrozoa, Bryozoa, Porifera present

\section{Area II Strait of Magellan}

Others $11 \%$

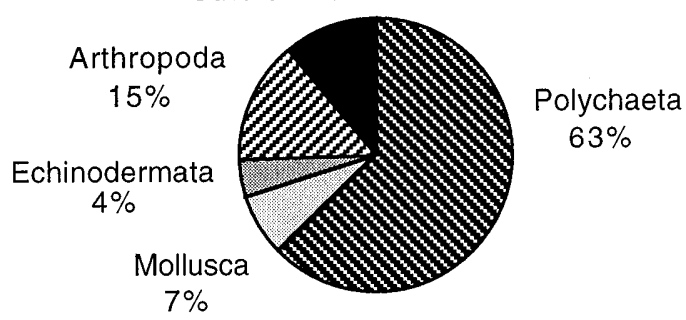

Arthropoda: Amphipoda 57\% Echinodermata: Ophiuroidea 61\% Cumacea $8 \%$

Isopoda $7 \%$

Crustacea sp. $7 \%$

Pantopoda $7 \%$

Ostracoda 5\%

Tanaidacea $4 \%$

Cirripedia $4 \%$

Acari $1 \%$

Mollusca: Bivalvia $82 \%$

Polyplacophora $8 \%$

Gastropoda $8 \%$

Solenogastres $1 \%$

(a)

Scaphopoda 1\%

Fig. 2 a Relative proportions of taxa in macrozoobenthic abundance b Relative proportions in macrozoobenthic biomass

\section{Area III Beagle Channel}

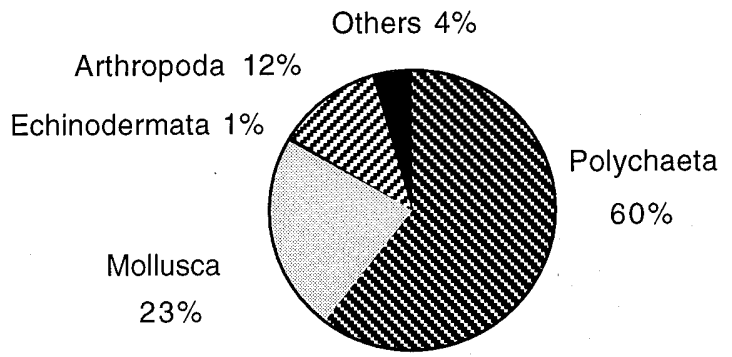

Arthropoda: Amphipoda 50\% Ostracoda $16 \%$ Cumacea $11 \%$ Crustacea sp 9\% Isopoda 5\% Tanaidacea 5\% Pantopoda 3\% Harpacticoidea $1 \%$

Mollusca: Bivalvia $68 \%$ Gastropoda $27 \%$ Polyplacophora 3\% Solenogastres 1\% Scaphopoda $1 \%$

\section{Echinodermata: Ophiuroidea 50\% Holothuroidea $17 \%$ Asteroidea 17\% Echinoidea 16\% \\ Others: Sipunculida 55\% Vermes sp. $28 \%$ Unidentified $11 \%$ Brachiopoda 2\% Echiurida $2 \%$ Priapulida $2 \%$}

Hydrozoa, Bryozoa, Porifera present

\section{Area IV Continental shelf}

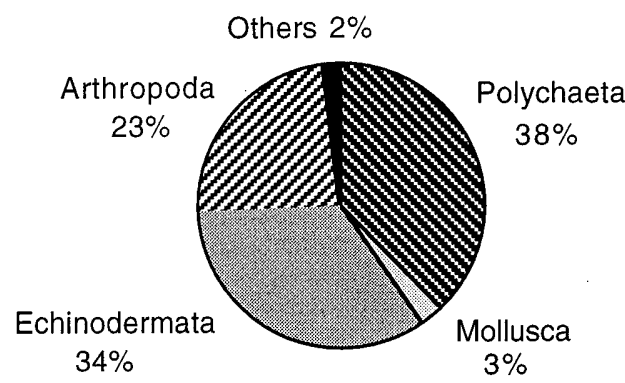
Holothuroidea $32 \%$ Echinoidea 5\% Asteroidea $2 \%$ Others :Vermes sp $68 \%$ Unidentfied $15 \%$ Sipunculida $6 \%$ Nemertini spp 4\% Brachiopoda 3\% Anthozoa 1\% Tunicata $1 \%$ Acrania 1\% Priapulida $1 \%$

\section{Arthropoda: Amphipoda $64 \%$ Echinodermata: Ophiuroidea $90 \%$ Tanaidacea $16 \%$ Isopoda $15 \%$ Crustacea sp $2 \%$ Ostracoda $2 \%$ Cumacea $1 \%$ \\ Mollusca : Bivalvia 54\% Polyplacophora $26 \%$ Gastropoda $10 \%$ Holothuroidea $4 \%$ Crinoidea $3 \%$ Echinoidea $2 \%$ Asteroidea 1\% Others: Brachiopoda 37\% Vermes sp. $36 \%$ Anthozoa 11\% Sipunculida $10 \%$ Priapulida 11\% Tunicata 5\%}

Hydrozoa, Bryozoa, Porifera present 
Area I South Patagonian Ice-Field

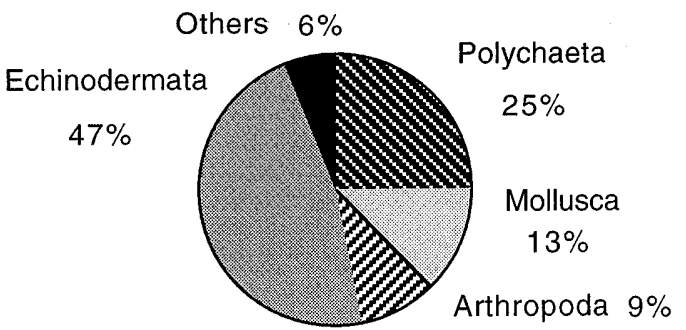

Echinodermata: Echinoidea $49 \%$ Holothuroidea $49 \%$

Arthropoda: Crustacea sp 95\% Pantopoda 1\% Amphipoda $1 \%$ Cumacea $1 \%$ Cirripedia $1 \%$ Ostracoda $1 \%$

Mollusca: Bivalvia 97\% Scaphopoda $2 \%$ Gastropoda 1\%

Asteroidea 1\% Ophiuroidea 1\%

Others: Bryozoa $72 \%$

Porifera $18 \%$ Vermes sp $2 \%$ Priapulida $2 \%$ Sipunculida $1 \%$ Tunicata 1\% Unidentified 2\% Hydrozoa 2\%

\section{Area II Strait of Magellan}

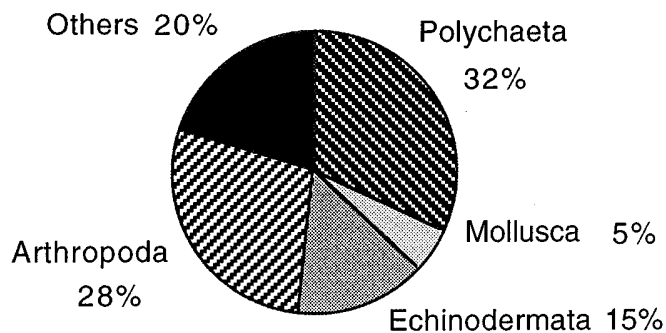

\begin{tabular}{|c|c|c|}
\hline Arthropoda: & $\begin{array}{l}\text { Cirripedia } 75 \% \text { Others: } \\
\text { Isopoda } 10 \% \\
\text { Crustacea sp } 6 \% \\
\text { Amphipoda } 4 \% \\
\text { Pantopoda } 1 \% \\
\text { Acari } 1 \% \\
\text { Cumacea } 1 \% \\
\text { Tanaidacea } 1 \% \\
\text { Ostracoda } 1 \% \\
\text { Bivalvia } 84 \% \\
\text { Gastropoda } 8 \% \\
\text { Solenogastres } 4 \% \\
\text { Polyplacophora } 2 \% \\
\text { Scaphopoda } 2 \%\end{array}$ & $\begin{array}{l}\text { Porifera } 47 \% \\
\text { Brachiopoda } 19 \% \\
\text { Vermes sp } 7 \% \\
\text { Nemertini spp } 6 \% \\
\text { Anthozoa } 6 \% \\
\text { Bryozoa } 6 \% \\
\text { Hydrozoa } 4 \% \\
\text { Unidentified } 2 \% \\
\text { Sipunculida } 1 \% \\
\text { Tunicata } 1 \% \\
\text { Priapulida } 1 \% \\
\text { Echinodermata: } \\
\text { Asteroidea } 36 \% \\
\text { Ophiuroidea } 31 \% \\
\text { Echinoidea } 22 \% \\
\text { Holothuroidea } 11 \%\end{array}$ \\
\hline
\end{tabular}

\section{Area III Beagle Channel}

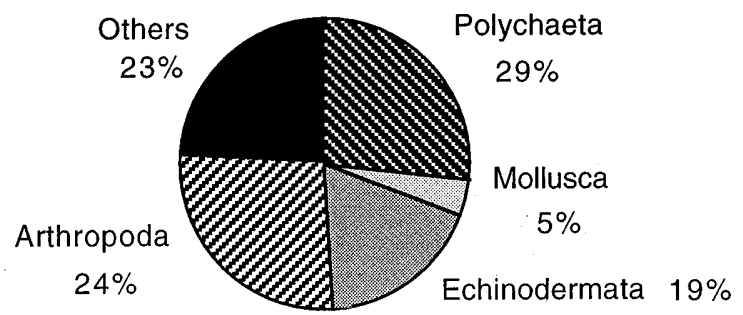

\section{Area IV Continental shelf}

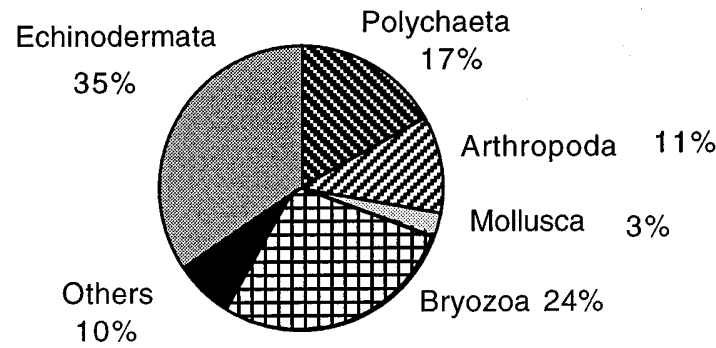

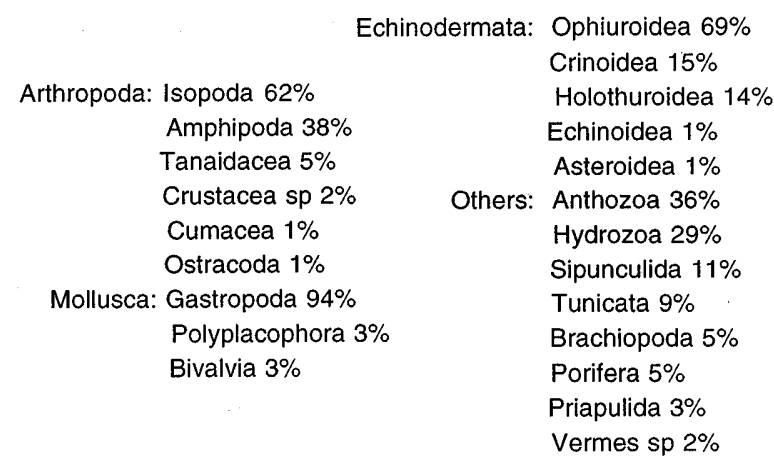

ciers and heavy rainfalls. There is a conspicuous gradient of decreasing salinity and temperature towards the glacier tongues (Pinochet and Salinas 1996). The sediment composition in this area is affected by glacier scouring, which leads to the deposition of mud and gravel. Our data allow us to differentiate between an impoverished fjord community and a richer channel community. This pattern was also evident in the composition of Agassiz trawl catches carried out in this region (W.E. Arntz, personal communication). Large and long-lived echinoderms and molluscs, mostly bivalves, were found, making up $60 \%$ of the whole biomass. 
The Strait of Magellan with its adjacent channels and fjords (area II) and the Beagle Channel (area III) are characterized by strong currents, inducing various types of sediment (Brambati et al. 1991): deposition zones of mud and clay in the Paso Ancho (Mariani et al. 1996) and in the Beagle Channel, as well as muddy habitats in the adjacent Bahía Inútil and Seno Almirantazgo which are, in addition, strongly affected by the sediment input due to the rub-down of glaciers. The sediments at the Pacific and Atlantic sites are coarser. Moreover, high proportions of shell debris (Chlamys sp.) occurred at the Pacific coast. Mean temperature and salinity are higher in the strait $\left(7-9^{\circ} \mathrm{C}\right.$, $30 \% \mathrm{~S}$; Artegiani and Paschini 1991) than in the SPI area $\left(4-6^{\circ} \mathrm{C}, 14-30 \% \mathrm{~S}\right.$; Pinochet and Salinas 1996). The benthos is dominated by polychaetes. The abundance of this taxon increased towards the Atlantic, a finding that was also observed by Mariani et al. (1996). In terms of environmental conditions, the Beagle Channel is more similar to the SPI (Colizza 1991), with lower surface salinity and temperature $\left(27 \% \mathrm{~S}, 6.5-8^{\circ} \mathrm{C}\right.$; Antezana et al. 1996). However, in macrobenthic composition it is more similar to the Strait of Magellan. The only difference was the higher presence of molluscs and the lower density of sponges in the Beagle Channel.

Sediments at the continental slope (area IV) are characterized by fine sand, mixed with shell debris. Echinoderms, arthropods and especially bryozoans dominated the macrobenthic community. Generally, the faunistic composition was more similar to the Antarctic shelf (Gerdes et al. 1992) than to the other Magellan sampling sites.

\section{Comparison to Weddell Sea benthos}

Based on data from the Paso Ancho and the Beagle Channel, which showed the highest abundance and biomass of the Magellan region, Brey and Gerdes (in press) reported that benthic community production and productivity were higher in the Magellan region than in the Weddell Sea. They assumed a better food supply and higher ambient temperatures to be responsible for this finding. Conversely, the analysis of our larger database suggests that production and productivity, as well as abundance and biomass, are lower in the Magellan region (Table 1) than in the high Antarctic $\left(3.6 \mathrm{gC} \mathrm{m}^{-2}\right.$, $0.3 \mathrm{gC} \mathrm{m}^{-2}, 3806$ ind. $\mathrm{m}^{-2}, 12 \mathrm{gC} \mathrm{m}^{-2}$, Brey and Gerdes, in press).

Antarctic biomass, especially on the shelf, has frequently been shown to be outstandingly high (Dayton et al. 1974; White 1984; Brey and Gerdes 1997). Lower values from shallow waters $(<10 \mathrm{~m})$ have been proposed to be mainly caused by ice impact or by low and seasonally pulsed food supply (Dayton and Oliver 1977; White 1984). However, subtidal areas such as those in the Magellan region can also be characterized as rather stressful environments, due to tidally varying temperature, salinity and currents (Levinton 1982). The decrease of abundance and biomass with water depth is a common pattern and has been reported from numerous regions such as, for instance, from the high-Antarctic Weddell and Lazarev Seas (Brey and Gerdes, 1998).

We have detected a clear increase of abundance, biomass and production with latitude within the Magellan region. However, it is not clear whether this gradient extends towards the Antarctic Peninsula, as suggested by the data available for this region from the literature (e.g. Richardsen and Hedgpeth 1977; Mühlenhardt-Siegel 1988). Future community analyses at species level are needed to work out more detailed differences and similarities between the Magellan study area and the Antarctic Peninsula.

Acknowledgements The authors are grateful to the International Bureau of the German Ministry of Research (BMBF) for the intensive support and cooperation during the years. We would also like to thank Wolf Arntz and Thomas Brey for critically reading the manuscript. This is Alfred Wegener Institute Publication No. 1488.

\section{References}

Antezana T, Hamamé M, Eissler Y, Jara S (1996) Hydrography in Chilean fjords: strait of Magellan to Beagle Channel. Cruise report of the Joint Chilean-German-Italian Magellan "Victor Hensen" Campaign in 1994. Ber Polarforsch 190:16-18

Arntz WE, Gorny M (1996) Cruise report of the Joint ChileanGerman-Italian Magellan "Victor Hensen" Campaign in 1994. Ber Polarforsch 190:1-85

Arntz WE, Brey T, Gallardo VA (1994) Antarctic zoobenthos. Oceanogr Mar Biol Annu Rev 32:241-304

Artegiani A, Paschini E (1991) Hydrological characteristics of the Straits of Magellan: austral summer 1990/91 (February-March 1991). Mem Biol Mar Oceanogr 19:77-81

Atkinson EG, Wacasey JW (1976) Caloric values of zoobenthos and phytobenthos from the Canadian Arctic. Fish Mar Ser Tech Rep 632:1-32

Barthel D (1995) Tissue composition of sponges from the Weddell Sea, Antarctica: not much meat on the bones. Mar Ecol Prog Ser 123:149-153

Brambati A, Fontolan G, Simeoni U (1991) Recent sediments and sedimentological processes in the Strait of Magellan. Boll Oceanol Teor Appl IX:2-3

Brandt A (1991) Zur Besiedlungsgeschichte des antarktischen Schelfes am Beispiel der Isopoda (Crustacea, Malacostraca). Ber Polarforsch 98:1-240

Brattström H, Johanssen A (1983) Ecological and regional zoogeography of marine benthic fauna. Report No. 49 of the Lund University Chile Expedition 1948-1949. Sarsia 68:289-339

Brey T, Gerdes D (1997) Is Antarctic benthic biomass really higher than elsewhere? Antarct Sci 9:266-267

Brey T, Gerdes D (in press) Benthic community productivity in the Magellan region and in the Weddell Sea. Sci Mar

Brey T, Gerdes D (1998) High Antarctic macrobenthic community production. J Exp Mar Biol Ecol 231:191-200

Brey T, Rumohr H, Ankar S (1988) The energy content of macrobenthic invertebrates: general conversion factors from weight to energy. J Exp Mar Biol Ecol 117:271-278

Brey T, Jarre-Teichmann A, Borlich O (1996) Artificial neural network versus multiple linear regression: predicting $\mathrm{P} / \mathrm{B}$ ratios from empirical data. Mar Ecol Prog Ser 140:251-256 
Colizza E (1991) Preliminary report on coastal morphology and sea-bottom sediments of the Canales Beagle, Ballenero, Brecknock, Cockburn, and Magdalena. Boll Oceanol Teor Appl 9:2-3

Cummins KW, Wuycheck JC (1971) Caloric equivalents for investigations in ecological energetics. Int AssocTheor Appl Limnol Commun 18:1-158

Dahm C (1996) Ecology and population dynamics of Antarctic ophiuroids. Ber Polarforsch 194:1-289

Dauvin JC, Joncourt M (1989) Energy values of marine benthic invertebrates from the western English Channel. J Mar Biol Assoc UK 69:589-595

Dayton PK, Oliver JS (1977) Antarctic soft-bottom benthos in oligotrophic and eutrophic environments. Science 197:55-58

Dayton PK, Robillard GA, Paine RT, Dayton LB (1974) Biological accommodation in the benthic community at McMurdo Sound, Antarctica. Ecol Monogr 44:105-128

Fahrbach E, Gerdes D (1997) The Expedition Antarktis XIII/4-5 of the Research Vessel "Polarstern" in 1996. Ber Polarforsch 239:1-126

Gerdes D (1990) Antarctic trials with the multibox corer, a new device for benthos sampling. Polar Rec 26:35-38

Gerdes D, Montiel A (in press) Distribution patterns of macrozoobenthos: a comparison between the Magellan region and the Weddell Sea (Antarctic). Sci Mar

Gerdes D, Klages M, Arntz WE, Herman RL, Galéron J, Hain S (1992) Quantitative investigations on macrobenthos communities of the southeastern Weddell Sea shelf based on multibox corer samples. Polar Biol 12:291-301

Gorny $\mathrm{M}$ (in press) Biogeography and ecology of decapod crustaceans in the Southern Ocean. Sci Mar

Levinton JS (1982) Marine ecology. Prentice-Hall, Englewood Cliffs, NJ

Linse K (1997) Distribution of epibenthic Mollusca from the Chilean Beagle Channel. Ber Polarforsch 228:1-131

Mariani S, Gambi MC, Lorenti M, Mazzella L (1996) Benthic populations of the soft bottoms in the Strait of Magellan (Southern America): biodiversity, distribution and biogeogra- phy of polychaetes and crustacean isopods. Biol Mar Mediterr 3:155-158

Mühlenhardt-Siegel U (1988) Some results on quantitative investigations of macrozoobenthos in the Scotia Arc (Antarctica). Polar Biol 8:241-248

Mutschke E, Rios C, Gorny M (1995) Estudio bentónico en fiordos y canales patagónicos y fueguinos. Crucero de Investigación Científica Marina a los Fiordos y Canales adyacentes a Campos de Hielo sur. Informe de Crucero. Comité Oceanográfico Nacional, Concepcion, pp 72-85

Pinochet P, Salinas S (1996) Estructura térmica y salina de canales y fiordos adyacentes a los campos de Hielo Sur. Crucero de Investigación Científica Marina a los Fiordos y Canales adyacentes a Campos de Hielo sur. Informe de Crucero. Comité Oceanográfico Nacional, Concepcion, p 122

Reineck HE (1963) Der Kastengreifer. Nat Mus 93:102-108

Richardson MD, Hedgpeth JW (1977) Antarctic soft-bottom, macrobenthic community adaptations to a cold, stable, highly productive, glacially affected environment. In: Llano GA (ed) Adaptations within Antarctic ecosystems. Proceedings of the 3rd SCAR Symposium on Antarctic Biology. Smithsonian Institution, Washington, DC, pp 181-196

Rumohr H, Brey T, Ankar S (1987) A compilation of biometric conversion factors of benthic invertebrates of the Baltic Sea. Baltic Mar Biol Publ 9:1-56

Steimle FW, Terranova RT (1985) Energetic equivalents of marine organisms from the continental shelf of the temperate Northwest Atlantic. J Northwest Atl Fish Sci 6:117-124

Wacasey JW, Atkinson EG (1987) Energy values of marine benthic invertebrates from the Canadian Arctic. Mar Ecol Prog Ser 43:243-250

Walker M, Tyler PA, Billett DSM (1987) Organic and calorific content of body tissues of deep-sea elapsoid holothurians in the northeast Atlantic Ocean. Mar Biol 96:277-282

Warren CR, Sugden DE (1993) The Patagonian icefields: a glaciological review. Arct Alp Res 25:316-331

White MG (1984) Marine benthos. In: Laws RM (ed) Antarctic ecology, vol 2. Academic Press, London, pp 421-461 